\title{
PENGARUH RASIO KECUKUPAN MODAL, LIKUIDITAS DAN OPERASIOAL TERHADAP KINERJA KEUANGAN BANK SYARIAH DI INDONESIA (STUDI EMPIRIS PADA BRI SYARIAH)
}

\author{
Iqra Wiarta \\ DosenUniversitas Muhammadiyah Jambi \\ iqra_wiarta2006@yahoo.co.id
}

\section{Ringkasan}

Tujuan penelitian ini yaitu untuk menguji dan mengetahui seberapa besar pengaruh rasio kecukupan modal yaitu Capital adequacy Ratio (CAR) dan rasio beban operasional yaitu Biaya Operasional terhadap beban operasioanl (BOPO) dan rasio likuiditas yaitu Financiang to Deposit Ratio (FDR) terhadap kinerja laba yaitu rasio Return on Asset (ROA) Bank Syariah di Indonesia studi kasus pada Bank Rakyat Indonesia Syariah (BRIS) periode 2010 sampai dengan 2019. Data yang digunakan pada penelitian ini bersumber pada laporan keuangan tahunan Bank Rakyat Indonesia Syariah periode 2010 sampai dengan 2019. Metode penelitian ini menggunakan analisis regresi linier berganda dengan alatnya yaitu spss 23.

Hasil penelitian menunjukan bahwa semua variabel independent yaitu CAR, BOPO dan FDR berpengaruh secara bersama-sama terhadap ROA. Sedangkan untuk pengaruh masing - masing variabel hanya variabel FDR yang berpengaruh positif terhadap ROA sedangkan CAR dan BOPO berpengaruh negatif terhadap ROA.

Kata Kunci: BOPO, CAR, FDR dan ROA

\section{PENDAHULUAN}

Industri Jasa keuangan syariah saat ini merupakan salah satu sektor yang menjadi pergerak perekonomian di Indonesia. Salah satu sektor dalam industri jasa keuangan syariah yaitu sektor perbankan syariah, yang berkembang pesat pada kurun waktu beberapa tahun ini. Perkembangan yang sangat pesat tersebut membuat persaiangan antara bank akan menjadi tinggi sehingga diperlukan kinerja yang baik dari bank tersesbut. Kinerja dari suatu bank dapat dilihat dari laporan keuangan bank itu sendiri yang dipublikasi sebagai bentuk transparasi dalam mencapai Good Corporate Governance. Laporan keuangan itu sendiri merupakan penilaian terhadap kinerja keuangan dari perbankan tersebut dalam bidang permodalan, operasional, likuiditas dan kinerja keuangan bank dalam menghasilkan laba dalam kurun waktu tertentu.

Menurut Aditya (2013) beberapa faktor yang berpengaruh terhadap kinerja keuangan yaitu ROA bank syariah CAR, BOPO NPF dan FDR. Rasio CAR berkaitan dengan permodalan suatu bank dalam menjalankan kegiatannya. Rasio BOPO merupakan perbandingan antara total biaya operasional dengan total pendapatan operasional dengan tujuan untuk mengukur seberapa sefisien kegiatan operasioanl bank syariah. Sedangkan rasio 
FDR merupakan rasio yang mengukur kemampuan bank untuk memenuhi kewajiban yang harus dipenuhi oleh bank tersebut. Berikut merupakan perkembangan rasio keuangan Bank Umum Syariah di Indonesia periode 2016 s/d 2019.

Tabel.1. Perkembangan kinerja keuangan Bank Umum Syariah di Indonesia

\begin{tabular}{|l|c|c|c|c|}
\hline Rasio / Tahun & 2016 & 2017 & 2018 & 2019 \\
\hline CAR & 16,63 & 17,91 & 20,39 & 20,11 \\
\hline ROA & 0,63 & 0,63 & 1,28 & 1,58 \\
\hline FDR & 85,99 & 79,61 & 78,53 & 80,09 \\
\hline BOPO & 96,22 & 94,91 & 89,19 & 85,99 \\
\hline
\end{tabular}

Sumber : OJK (2020)

Dari tabel diatas diketahui bahwa kinerja rasio keuangan Bank Umum syariah di Indonesia setiap tahun terus mengalami perubahan yang berfluktuatif. Seperti kinerja CAR bank Umum syariah di Indonesia selama tahun 2016 sampai dengan 2018 mengalami peningkatan setiap tahunnya akan tetapi pada tahun 2019 mengalami penurunan, begipula dengan kinerja rasio ROA yang pada tahun 2016 dan 2017 tidak mengalami perubahan akan tetapi kinerja pada tahun 2018 dan 2019 mengalami peningkatan. Kinerja rasio FDR dan BOPO juga mengalami perubahan baik pada tahun 2017 kinerja BOPO mengalami peningkatan akan tetapi pada 3 tahun berikutnnya mengalami penurunan kinerja. Kinerja rasio FDR juga mengalami penurunan pada tahun 2016 sampai dengan 2018 akan tetapi pada tahun 2019 mengalami peningkatan.

Bertolok dari latar belakang ini, maka penulis tertarik untuk meneliti lebih lanjut tentang kinerja keuangan terutama kinerja laba dari industri perbankan syariah di Indonesia dengan melakukan studi lebih lanjut untuk menguji apakah terdapat pengaruh rasio CAR, BOPO dan FDR terhadap ROA pada Bank Rakyat Indonesia Syariah periode 2011 sampai dengan 2019. Adapun penelitian ini akan menganalisis pengaruh rasio CAR, BOPO dan FDR terhadap ROA.

\section{LANDASAN TEORITIS}

\section{Capital Adequacy Ratio (CAR)}

Rasio kecukupan modal atau CAR menurut Mainata (2017) merupakan rasi kewajiban bank syariah dalam memnuhi modal minimum dengan bertujuan untuk menjaga likuiditas bak dan untuk mengukur kecukupan modal bank dalam menyerap kerugian dan pemenuhan ketentuan kewajiban penyedian modal minimum (KPMM) bank syariah.

Biaya Operasional per Pendapatan Operasional (BOPO) 
Menurut Dendawijaya (2003) rasio biaya operasional digunakan untuk mengukur tingkat efisiensi dan kemampuan bank syariah dalam melakukan kegiatan operasionalnya. Dengan demikian dapat disimpulkan bahwa rasio BOPO bertujuan untuk mengukur kemampuan pendapatan operasional bank syariah dalam menutup biaya operasionalnya. Semakin tinggi nilai BOPO menunjukan kurangnya efisiensi dari Bank syariah tersebut.

Financing to Deposit Ratio (FDR)

Menurut Riva'I dan Buchari (2009) Financing to Deposit Ratio (FDR) merupakan rasio yang membandingkan antara total pembiayaan dengan DPK (dana pihak ketiga) yang berhasil dikerahkan oleh bank syariah. Artinya adalah semakin tinggi nilai FDR suatu bank syariah maka memiliki potensi untuk menaikan laba bank tersebut.

Kinerja Keuangan (Profitabilitas/ROA)

Menurut Mainata (2017) Profitabilitas Bank syariah merupakan ukuran kemampuan bank dalam menghasilkan laba dengan memanfaatkan aktiva yang dimilikinya dalam suatu periode tertentu. Rasio Return On Asset (ROA) sering kali digunakan baik peneliti maupun investor dalam menghitung kinerja profitabilitas bank syariah. Menurut Mainata (2017) ROA merupakan rasio yang membandingkan antara laba bersih terhadap total aset. Sehingga semakin tinggi rasio ROA ini menunjukan semakin besar pula profit yang dihasilkan dari laba yang dimiliki oleh bank syariah.

\section{Metode Penelitian}

Pada penelitian ini data yang digunakan adalah data sekunder yang bersumber dari laporan tahunan Bank Rakyat Indonesia Syariah yang dijadikan sebagai objek dari penelitian tersebut pada periode 2011 sampai dengan 2019 yang di unduh pada halaman website Bank tersebut. Dalam melakukan penelitian ini, data yang diperoleh akan dianalisis dengan menggunakan model regresi linier berganda yang persamaannya dapat ditulis sebagai berikut :

$$
\mathrm{Y}=\mathrm{a}+\mathrm{b} 1 \mathrm{X} 1+\mathrm{b} 2 \mathrm{X} 2+\mathrm{b} 3 \mathrm{X} 3+\mathrm{e}
$$

Dimana : $\quad \mathrm{Y}=$ Return on Asset (ROA)

$\mathrm{a}=$ Konstanta

b1...b3 = Koefisien Regresi

$\mathrm{X} 1=\mathrm{CAR}$

$\mathrm{X} 2=\mathrm{BOPO}$

$\mathrm{X} 3=\mathrm{FDR}$

$\mathrm{E} \quad=$ error term 


\section{Hasil dan Pembahasan}

Bank Rakyat Indonesia syariah merupakan anak perusahaan dari PT. Bank Rakyat Indonesia Tbk dan merupakan bank umum syariah yang telah terbuka dan listing di Bursa Efek Indonesia pada tahun 2018. Berdasarkan hasil analisis deskripsi statistik dengan menggunakan alat SPSS 23 dalam menguji pengaruh antara CAR, BOPO dan FDR terhadap ROA maka didapatkan hasil penelitian sebagai berikut pada tabel dibawah ini :

\begin{tabular}{|c|c|c|c|c|c|c|}
\hline \multicolumn{7}{|c|}{ Coefficients ${ }^{\mathrm{a}}$} \\
\hline \multirow{2}{*}{\multicolumn{2}{|c|}{ Model }} & \multicolumn{2}{|c|}{ Unstandardized Coefficients } & $\begin{array}{c}\text { Standardized } \\
\text { Coefficients }\end{array}$ & \multirow[b]{2}{*}{$\mathrm{t}$} & \multirow[b]{2}{*}{ Sig. } \\
\hline & & $\mathrm{B}$ & Std. Error & Beta & & \\
\hline 1 & (Constant) & 9,534 & 991 & & 9,623 &, 000 \\
\hline & CAR &,- 003 &, 007 &,- 057 &,- 467 & 657 \\
\hline & BOPO &,- 096 & 009 &,- 949 & $-10,702$ &, 000 \\
\hline & FDR & 003 & 004 & 089 &, 731 & 492 \\
\hline
\end{tabular}

a. Dependent Variable: ROA

Maka dapat disimpulkan persamaan transformasi regresi linear berganda sebagai berikut :

$\mathrm{ROA}=9,534+(-0,003) \mathrm{CAR}+(-0,096) \mathrm{BOPO}+0,003 \mathrm{FDR}+\mathrm{E}$

Dari persamaan tersebut dapat dijabarkan bahwa persamaan regresi linier berganda memiliki konstanta posistif sebesar 9,534 yang artinya jika CAR, BOPO dan FDR sama dengan nol maka akan terjadi peningkatan laba atau nilai ROA sebesar 9,534. Koefisien CAR $=-0,003$ menunjukan arti bahwa setiap kenaikan CAR sebesar $1 \%$ akan menyebabkan penurunan ROA sebesar 0,003\% begitu pula untuk BOPO yang memiliki nilai koefisien negatif sebesar -0,096 yang artinya adalah setiap kenaikan nilai BOPO sebesar 1\% maka akan menyebabkan penurunan nilai ROA sebesar 0,096\%. Untuk koefisien FDR sebesar 0,003 menunjukan arti bahwa setiap kenaikan nilai FDR sebesar 1\%, akan diikuti kenaikan nilai dari ROA sebesar $0,003 \%$. Selanjutnya untuk melihat pengaruh variabel bebas secara bersama sama terhadap variabel independet maka dapat dilihat pada tabel dibawah ini :

\begin{tabular}{|ll|r|r|r|r|r|}
\hline \multicolumn{1}{|c|}{} & & ANOVA & \\
\hline 1 & Sum of Squares & df & Mean Square & F & Sig. \\
\hline & Regression & 1,080 & 3 &, 360 & 41,297 &, $000^{\mathrm{b}}$ \\
& Residual &, 052 & 6 &, 009 & & \\
& Total & 1,133 & 9 & & & \\
\hline
\end{tabular}

a. Dependent Variable: ROA

b. Predictors: (Constant), FDR, BOPO, CAR

Dari tabel Anova diatas, didapatkan hasil pengujian pengaruh variabel secara simultan yang lebih keci dari 0,05 atau 5\%. Sehingga dapat dikatakan bahwa seluruh variabel berpengaruh secara signifikan terhadap variabel terikat. 


\section{KESIMPULAN}

Dari hasil penelitian dapat disimpulkan bahwa CAR, BOPO dan FDR mempengaruhi kinerja laba Bank syariah yaitu ROA secara bersama - sama dan individual. Dari tiga variabel dependent dalam penelitian tersebut yaitu CAR berpengaruh negatif terhadap ROA sebesar 0,003 begitu pula BOPO berpengaruh negatif terhadap ROA sebesar - 0,096 sedangkan untuk variabel FDR berpengaruh positif terhadap ROA sebesar 0,03. Dengan demikian maka hipotesis 1 pada penelitian ini ditolak sedangkan untuk hipotesis 2 dan 3 diterima.

\section{DAFTAR PUSTAKA}

Aditya, A. M. (2013). Analisis Pengaruh CAR, FDR, NPF dan BOPO terhadap ROA Bank Umum Syariah (Studi kasus Bank Umum Syaiah di Indonesia Periode 2010 - 2012) Tesis, IAIN Sumatera Utara, Medan.

Annual report. (2014). Laporan Tahunan Bank Rakyat Indonesia Syariah. Jakarta. (2019). Laporan Tahunan Bank Rakyat Indonesia Syariah. Jakarta.

Cahyaningrum, N. H. (2012). Analisis Rasio Keuangan dalam Memprediksi Pertumbuhan Laba (Studi Kasus : Perusahaan Manufaktur yang Terdaftar di Bursa Efek Indonesia Periode 2005 sampai dengan 2010). Tesis Program Studi Magister Manajemen Program Pasca Sarjana Universitas Diponegoro, Semarang.

Dendawijaya, L. (2009). Manajemen Perbankan. Bogor: Ghalia Indonesia.

Hapsari, E.A. (2007). Analisis Rasio Keuangan untuk Memprediksi Pertumbuhan Laba (Studi Kasus : Perusahaan Manufaktur yang Terdaftar di Bursa Efek Jakarta Periode 2001 sampai dengan 2005). Tesis Program Studi Magister Manajemen Program Pasca Sarjana Universitas Diponegoro, Semarang.

Hanafi, M.M., \&Halim, A. (2009), Analisis Laporan Keuangan. Edisi 4, STIM YKPN, Yogyakarta.

Haryati, S. (2001). Analisis Kebangkrutan Bank. Jurnal ekonomi dan bisnis Indonesia. Jakarta: STIE Perbanas.

Maharddian, P. (2007). Analisis pengaruh rasio CAR, BOPO, NPL, NIM dan LDR terhadap kinerja keuangan perbankan, Tesis, Program Pascasarjana Universitas Diponegoro, Semarang.

Riyanto, B. (2001). Dasar-dasar Pembelanjaan Perusahaan. Edisi kelima, BPFE, Yogyakarta.

Surya, N.A.dkk, (2019). Pengaruh CAR dan BOPO terhadap ROA bank Syariah Pada tahun 2011- 2018. Jurnal Perisai: Islamic Banking adn Finance, Lamongan. 
Peraturan Bank Indonesia Nomor 6/10/PBI/2004 tentang Sistem Penilaian Kesehatan Bank Umum. Jakarta: Bank Indonesia.

Peraturan Bank Indonesia Nomor 13/24/DPNP/2011 tentang Sistem Penilaian Kesehatan Bank Umum. 2011. Jakarta: Bank Indonesia.

Putri, H.T. (2016). Analisis Pengaruh Rasio Keuangan RBBR Terhadap Pertumbuhan Laba Bank (Studi Kasus PT. Bank Central Asia (BCA) Tbk). Junal ilmiah Universitas Batanghari Jambi. 16(1), 28-34. 